\title{
12. The Context of HIV Transmission During the 2007 Election in Enga Province
}

\author{
Philip Gibbs and Marie Mondu ${ }^{1}$
}

\begin{abstract}
A team of civil society observers was commissioned by the National Research Institute to observe and study the 2007 election in Enga Province. One of the issues to consider was the impact of the election on the spread of HIV in the province. Arriving in Enga at the beginning of the nomination period, the writers found a widespread opinion that there was heightened sexual activity in the province during the election period.
\end{abstract}

We chose a number of ways to look for trends in both protected and unprotected sexual behaviour. These included comparison of birth rates for the 2002 election year and the year following that election; sexually transmitted infection (STI) figures around the time of the 1997, 2002 and 2007 elections; condom distribution and sale rates before and during the elections; money flow during and outside election time; the amount of time people stayed away from home campaigning during the election period compared to other times; the way and the extent to which candidates referred to HIV or AIDS in their election campaign speeches; the experience of 'campaign houses'; and, more generally, attitudes of people towards sex and the HIV epidemic.

Much of the information about sexual attitudes and behaviour was gathered in conversations with friends and wantok. When visiting Wabag Hospital and the nearby Yampu Health Centre to check birth and STI records we spoke with health workers there. We also observed what took place at night markets, at gambling places, in villages, and on the streets in Wabag town.

What follows is an account of those aspects of the electoral context that may impact on the transmission of HIV among the people of the Enga Province.

\footnotetext{
1 We wish to acknowledge the National Research Institute, AusAID, the Electoral Support Program, the Research Advisory Committee of the National AIDS Council Secretariat, Caritas Australia, members of the Electoral Commission, particularly those in Wabag, the Enga domestic observer team, and all those people in Enga and elsewhere who assisted in any way in the research for this paper.
} 


\section{Risk occasions}

The National HIV/AIDS Support Project (NHASP) Social Mapping Project for Enga (2005:17) notes how elections are a 'risk occasion' in Enga (along with 'church crusades'). As an occasion that affects the lives of the whole population over a number of months every five years, why is it so 'risky'? The mapping report notes that there are many rape cases associated with elections. This paper will show how the risk is far more complex than that.

The Papua New Guinea Electoral Commission (PNGEC) also recognized that elections can be risky occasions and commissioned Jane Cousins to help mainstream HIV and AIDS in the PNGEC and to develop strategies to counter what was perceived as an increased risk of infection at election time. The PNG National Elections 2007 HIV Prevention Intervention program produced a number of initiatives, including education workshops for returning and assistant returning officers, awareness materials, screening of a film on national television, cartoon strip messages in the national newspapers, and distribution of HIV and AIDS 'kits' containing posters, pamphlets, latex gloves and condoms.

Our initial enquiries with a variety of people in Enga also revealed a general opinion that there is an increase in sexual activity during the election period and that this could lead to increased spread of STIs, including HIV.

The challenge facing us as researchers was to develop methodologies to measure and assess the veracity of that opinion.

\section{Method}

We realize that there is little point in studying HIV rates given the limited timeframe for our study. There is no set time between exposure to the virus and a person getting tested and clinically diagnosed. A person might get infected during the elections but find out after many years. It is also possible for someone to be infected in one place, such as Port Moresby, and be tested in another, such as Wabag. With these limitations we looked for other measures indicating sexual behaviour that might lead to HIV transmission.

With no quantitative baseline study outside of election time, the researcher is faced with a number of challenges. One can document behaviour that appears to enhance risk and contributes to an increase in HIV transmission, but without a baseline it is hard to know if there is a difference in behaviour more generally in the population or in particular groups outside or within the election period. This difficulty influenced our use of indicators in the study. For example, consider 
an obvious indicator-condom sales. Condom sales give no clear indication of condom use, and increased condom distribution could possibly indicate increased sexual activity, though there is no direct link. Moreover, increased condom use has no direct relationship to increased or decreased risk of the spread of HIV since it does not tell us if there was more unprotected sex.

The indicators we chose do not supply proof in themselves; however, taken together they contribute to a picture of sexual activity and its context. Where possible, we tried to gather diachronic data-for example, STI rates in clinic records over a number of years.

We chose the following five markers for quantitative data:

- birth rates - we presume that an increase in the birth rate indicates an increase in unprotected sex some nine months previously

- rates of STIs - we presume that an increase in a biomarker such as the monthly STI rates at hospital clinics indicates an increase in unprotected sex in the previous month or two; this is compounded by the fact that there are various types of STIs, some being asymptomatic

- condom distribution and sales - increased distribution and sales is presumed to indicate a desire for protected sex

- cash flow-some link poverty to sex, others link excess cash; our presumption is that more available cash may lead to more opportunities to buy or sell sex; though, as we will show, cash is not the only commodity in transactional sex

- mobility - we presume that when people live away from home there is more chance of engaging in new sexual liaisons (this would most probably mean less opportunity for sex with one's regular partner).

As may be seen from the above discussion, it is difficult to show how elections 'actually' increase HIV transmission. Indicators at best show trends, but do not provide proof. Qualitative methods help us to interpret the meaning of quantitative markers and help illustrate why and how there may be an enhanced potential for HIV transmission in the context of an election. Some of the questions for which we sought answers were:

- Why do people think the elections may have an impact on increased HIV transmission?

- Is changing sexual terminology over the last three decades also a sign of changing attitudes and behaviour?

- Are there new dynamics influencing multiple sexual partnering during the election period?

- Given the risks, why are men and women prepared to engage in unprotected sex? 
- What interventions have been tried and to what effect?

Campaign houses are reputedly places associated with sexual activity. We felt that attending the nightly sessions in such houses would compromise our political neutrality. So, information about these houses was obtained from discussion with friends and other persons who did attend. We also asked several people who had extensive experience of campaign houses in 2002 and 2007 to give a firsthand account of life at those houses. Additionally, we observed what took place at night markets, gambling places, villages, and streets in Wabag.

\section{Principal findings}

\section{Birth rates}

Birth rates are obviously linked to unprotected sex. For this purpose, births at Wabag General Hospital in 2002 were compared with those of 2003 (Figure 12.1). Births in the first months of 2003 were significantly higher than in 2002, indicating that more conceptions took place in May-July 2002 (the election period) than in the previous non-election year 2001. Comparing births in 2008 with those of 2007 (Figure 12.2), one can see a general trend of higher numbers of births in the first half of 2008 with a significant increase in April, just nine months after the election.

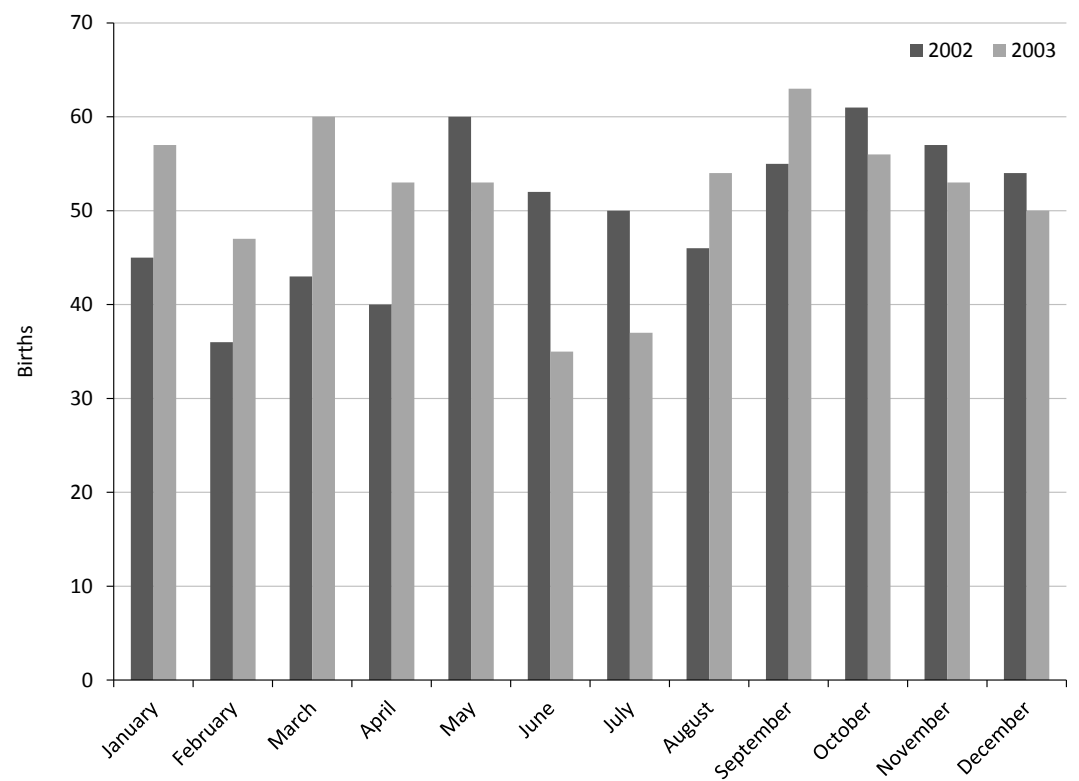

Figure 12.1: Monthly births at Wabag General Hospital, 2002 and 2003 


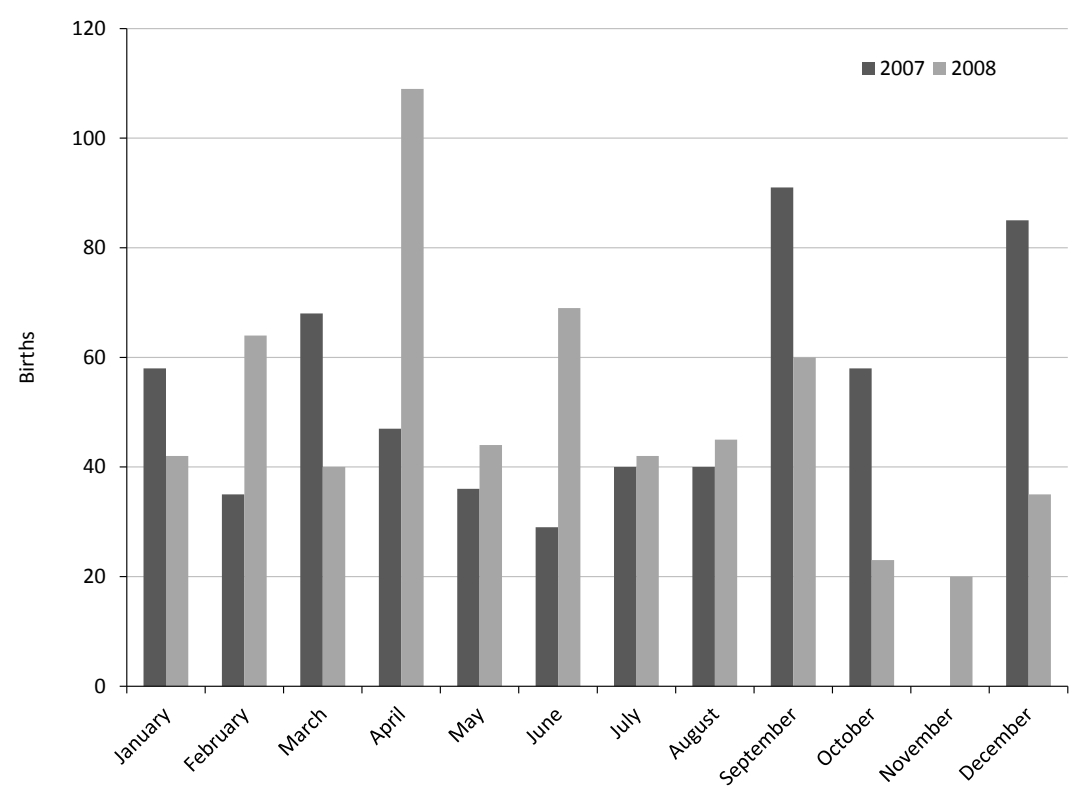

Figure 12.2: Monthly births at Wabag General Hospital, 2007 and 2008

Source: Birth records, Wabag General Hospital

\section{HIV and AIDS awareness education and public response}

As part of our election observation for Wabag Open, 24 campaign speeches were recorded, transcribed and analysed. Very few candidates mentioned HIV and AIDS. Exceptions to this were Maryanne Amu (who is a health worker by profession), Bart Philemon (who came to support his New Generation Party candidates) and Father Paul Kanda. The latter two did not focus on the HIV epidemic; rather, their focus was on corruption, and they used AIDS simply as an example of a problem with a negative effect on the community. On the basis of candidate posters, none of the contesting candidates had policies which addressed the HIV epidemic. As far as public campaigning went, HIV and AIDS appeared to be a non-issue.

We also looked at some of the awareness strategies used during the election process, either by the Provincial AIDS Committee (PAC) or by civil society, noting strengths and weaknesses of the different strategies. Table 12.1 summarizes our findings. 
Election 2007: The Shift to Limited Preferential Voting in Papua New Guinea

Table 12.1: Strengths and weaknesses of awareness strategies

\begin{tabular}{|c|c|c|c|c|}
\hline Approach & Organization & Weakness & Strength & Comment \\
\hline $\begin{array}{l}\text { Theatre or } \\
\text { drama group }\end{array}$ & $\begin{array}{l}\text { Mambisanda } \\
\text { Theatre } \\
\text { Group, Sari } \\
\text { Youth Group }\end{array}$ & $\begin{array}{l}\text { Performances } \\
\text { not } \\
\text { widespread. } \\
\text { Taken as } \\
\text { entertainment }\end{array}$ & $\begin{array}{l}\text { Use of local } \\
\text { language. } \\
\text { Engaged } \\
\text { community }\end{array}$ & $\begin{array}{l}\text { The group } \\
\text { experienced logistic } \\
\text { problems, limiting } \\
\text { the scope of their } \\
\text { activities }\end{array}$ \\
\hline $\begin{array}{l}\text { Training of } \\
\text { returning } \\
\text { officers and } \\
\text { election } \\
\text { officials }\end{array}$ & PAC & $\begin{array}{l}1 \text { day for } 2 \\
\text { hours only as } \\
\text { opposed to a } \\
\text { full day }\end{array}$ & $\begin{array}{l}17 \text { participants } \\
\text { attended and } \\
\text { materials } \\
\text { distributed }\end{array}$ & $\begin{array}{l}\text { Many were not } \\
\text { interested and left } \\
\text { the room one by one } \\
\text { (report by attendee) }\end{array}$ \\
\hline $\begin{array}{l}\text { Information } \\
\text { education } \\
\text { communication } \\
\text { materials } \\
\text { and condom } \\
\text { distribution }\end{array}$ & $\begin{array}{l}\text { PNGEC } 2007 \\
\text { Election HIV } \\
\text { Response } \\
\text { Program and } \\
\text { Enga PAC }\end{array}$ & $\begin{array}{l}\text { Late delivery; } \\
\text { no follow up } \\
\text { education }\end{array}$ & $\begin{array}{l}\text { Condoms and } \\
\text { other materials } \\
\text { available to the } \\
\text { public }\end{array}$ & $\begin{array}{l}\text { Distribution began } \\
\text { only on polling day. } \\
\text { When asked, many } \\
\text { people seemed not } \\
\text { to know how to } \\
\text { interpret the posters. } \\
\text { Some obtained the } \\
\text { colourful posters to } \\
\text { decorate the walls of } \\
\text { their houses. Others } \\
\text { took condoms to sell. }\end{array}$ \\
\hline Mass media & $\begin{array}{l}\text { PNGEC } 2007 \\
\text { Election HIV } \\
\text { Response } \\
\text { Program }\end{array}$ & $\begin{array}{l}\text { Local public } \\
\text { radio (NBC) } \\
\text { not on air prior } \\
\text { to election. } \\
\text { Majority has } \\
\text { no access to } \\
\text { TV and print } \\
\text { media }\end{array}$ & & $\begin{array}{l}\text { NBC resumed } \\
\text { broadcasting during } \\
\text { the counting period, } \\
\text { reporting full time on } \\
\text { election results }\end{array}$ \\
\hline
\end{tabular}

\section{STI rates}

Most STI infections show symptoms within a few weeks of sexual contact. Hence data for the months of June, July and August of election years might give an indication of unprotected sex during the campaign period, normally the months of April and May. Data from the Wabag STI clinic records do not show any clear trends for 2002; however, the data for 2007 shows a remarkable increase in people going for STI treatment in the months following the election (Figure 12.3).

Apart from statistics, verbal opinions of clinic staff were noted. Staff of Wabag STI clinic confirmed an increased number of patients after the campaigning months (May-June 2007). Mr Joel Mosek, who heads the clinic, made the following remarks on STI infections for election years: 
After the elections, I am expecting more patients. In every election, the number of STI patients is usually higher than normal days. And I believe more people will come in for treatment after this election (STI clinic, Wabag, 13 July 2007).

The high STI rate in Papua New Guinea has direct implications for HIV transmission. STIs are a sensitive marker of unprotected sexual behaviour that put people at risk of HIV infection, and are co-factors increasing the probability of HIV infection (Jenkins and Buchanan-Aruwafu 2007:79). Dr William Waro from the Wabag General Hospital, basing his comments on the National AIDS Council Secretariat Quarterly Report (December 2006), stated that Enga ranked second highest in the country on HIV infection by province. A total of 643 Engans were identified as HIV-positive at different testing centres in the country in 2006. The level of stigma and discrimination is extremely high, resulting in many infected individuals travelling out of the province to be tested elsewhereproducing a lower detection rate in the Enga Province. The impact of the 2007 election remains to be seen.

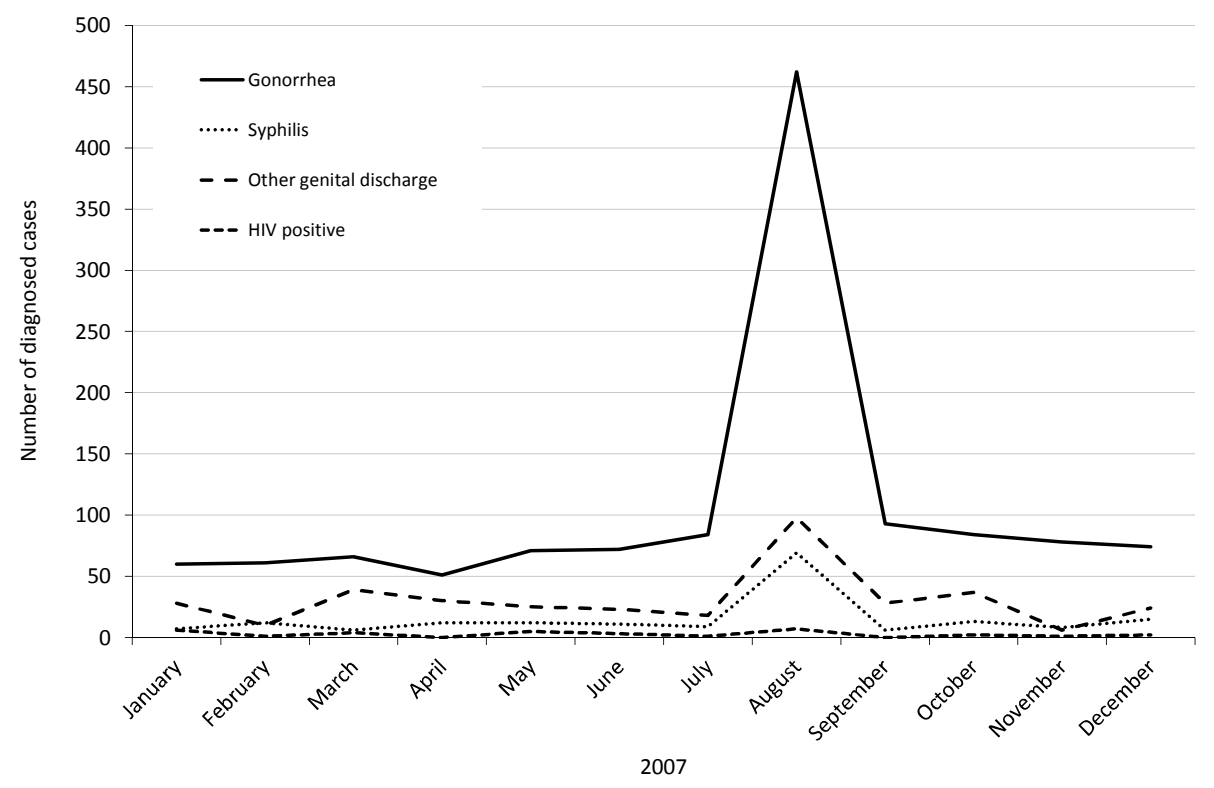

Figure 12.3: Total sexually transmitted infection cases diagnosed at Wabag STI clinic, 2007

Source: STI clinic, Wabag General Hospital 


\section{Condoms}

We sought data on condom distribution in order to assess availability and whether or not protected sex was common during elections. We found that condoms generally were available from the Enga PAC, shops, street sellers and local groups engaged in awareness activities. However, we have also identified attitudes affecting people's inability or unwillingness to use condoms despite their availability.

\section{HIV/AIDS response program 2007 national elections}

A total of 175 cartons containing information education communication (IEC) materials were received by Enga PAC two weeks before the campaign period. Distribution of these materials, however, came into effect two weeks after polling; thus polling teams did not receive the 'HIV kit' as planned. The delay was due to limited human resources at the PAC headquarters in Wabag. On polling day HIV/AIDS posters were given out to voters in some polling places. There was also a theatre group from Mambisanda that helped distribute IEC materials to campaign houses during the campaign period, and the assistant election manager obtained five boxes of male condoms from the PAC for provision to election officials.

Groups and individual advocates visited the PAC office occasionally, from the beginning of the campaign period through to the time of counting, to obtain supplies of IEC materials (personal communication, Mr James Balos, Coordinator of Enga PAC). Corporate houses and targeted workforce groups such as the Defence Force and Guard Dog Security personnel were supplied with IEC materials. Villages, schools and health facilities alongside the highway towards both Mount Hagen and Porgera were given similar packages, mostly during the counting period.

\section{Local distributors}

Local distributors comprise mainly local men and women who collect boxes or packets of condoms from health clinics, during awareness campaigns or directly from the PAC office. Local distributors sold condoms for 50 toea per packet. When the demand is high, a packet goes for K2. Selling of condoms provides a means of income for local distributors as well. One distributor said he was saving lives and making a little pocket money besides.

Reporting on sales during the elections, one vendor told us that usually on normal days, before elections, he sells half to one box of condoms per day (a box contains 12 condoms). During the campaigning period he sold four to five 
boxes per day (50-60 condoms) as he moved from one "“animal" [campaign] house' to another. However, when asked if he used condoms with his girlfriend, he denied it, claiming his girlfriend was a wapra [prostitute]. Through some sort of strange logic he expressed fear that condoms have holes in them and he could easily get infected, so he doesn't use them with her. An example like this indicates knowledge gaps about condoms as a preventative measure.

\section{Shops and retail outlets}

Apart from street sellers, retail outlets in town sell condoms. Two Asianowned shops were observed. One was selling male lubricated condoms that were commonly supplied by the National AIDS Council Secretariat. The shop assistant reported that the condom boxes were usually bought from the PAC office for K2.50 per box. Each condom was then sold for 30 toea. The second was selling imported condoms and claimed to have had many more customers purchasing condoms during the election period.

A tradestore keeper at Yampu near Wabag said that just before the issue of writs a health extension officer gave 15 cartons of condoms (each containing 12 boxes of 12 packets of condoms) to groups of young men in the area. Hence there was little need for people to buy them again, though he had customers from further afield. Before the election period he sold 10 to 12 condoms per week, but during the campaign period he was selling at the rate of about 70 condoms per week. Another tradestore keeper in the vicinity of a campaign house near Wabag said that during 2006 he sold about two boxes of condoms per month. In 2007 he was selling two boxes per week, and during the campaign period the demand increased to three to four boxes (36-48 condoms) per week. After the campaign period and voting, the demand went down again to one or two boxes per week.

\section{Condom use}

A large volume of condoms distributed does not mean that they are used by everybody. It seems that both male and female condoms were used. A local condom seller reported that before the election she sold to only three female relatives but during the election period word got around and many people came buying both female and male condoms. Women would say, 'In case the men do not have condoms we will use our condom'.

However, on a number of occasions we heard comments such as:

I don't like using condom because skin to skin is very nice and [more] satisfying than using this plastic called condom. It disturbs my sexual enjoyment (19-year-old male). 
I don't use condom because using condom does not satisfy my sexual desires. When I don't use condom I am well satisfied (25-year-old male).

I don't use condoms because it disturbs my sexual interactions with the ladies and does not satisfy my sexual desires. Skin to skin is the best way to satisfy me (29-year-old male).

I don't use condoms because most times I'm dead drunk. My attitude has changed. Usually before the elections I take alcohol and don't engage in sexual activities. During the elections, there were surplus of ladies around so I took the opportunity. Whichever campaign house I visit I hit it (had sex) Mi save paitim yet. I had at least one or two ladies a day (Male leader at his local church).

A woman who frequented campaign houses made the following comments:

I don't have to carry condoms around. That's men's responsibility. I don't care if they use condom or not. It's not only me who is going to be infected they will be infected too. So I don't worry too much about using condoms during sex.

To the extent that such attitudes are commonly held, despite distribution of condoms a considerable number of people are at risk of becoming infected.

\section{Cash flow}

Money was chosen as an indicator because cash is associated with sex and the spread of STI infections.

There is a trend toward a very high cash flow within the province at the time of election. Contesting candidates and their supporters used huge sums of cash to pay for votes, ranging from K5 to K100 per head, and time spent on gambling increased. Shop managers were interviewed and financial reports for the months of April, May, June and July 2007 were sighted. In all cases income had increased during the election period. Shop assistants confirmed that the election period was a peak period for business operations - one commented that the shop she was working in closed around 6pm during the election time- - an hour beyond the usual closing time.

With a ban on the open sale of alcohol in the province, Coca Cola often substitutes as a medium of exchange (along with money and pigs) at campaign rallies and other gatherings. It is difficult to obtain data on the amount of cash or the number of pigs exchanged. However, taking Coca Cola sales as a surrogate variable for cash flow, one can see from Figure 12.4 how sales increased almost seven-fold during the election period. 


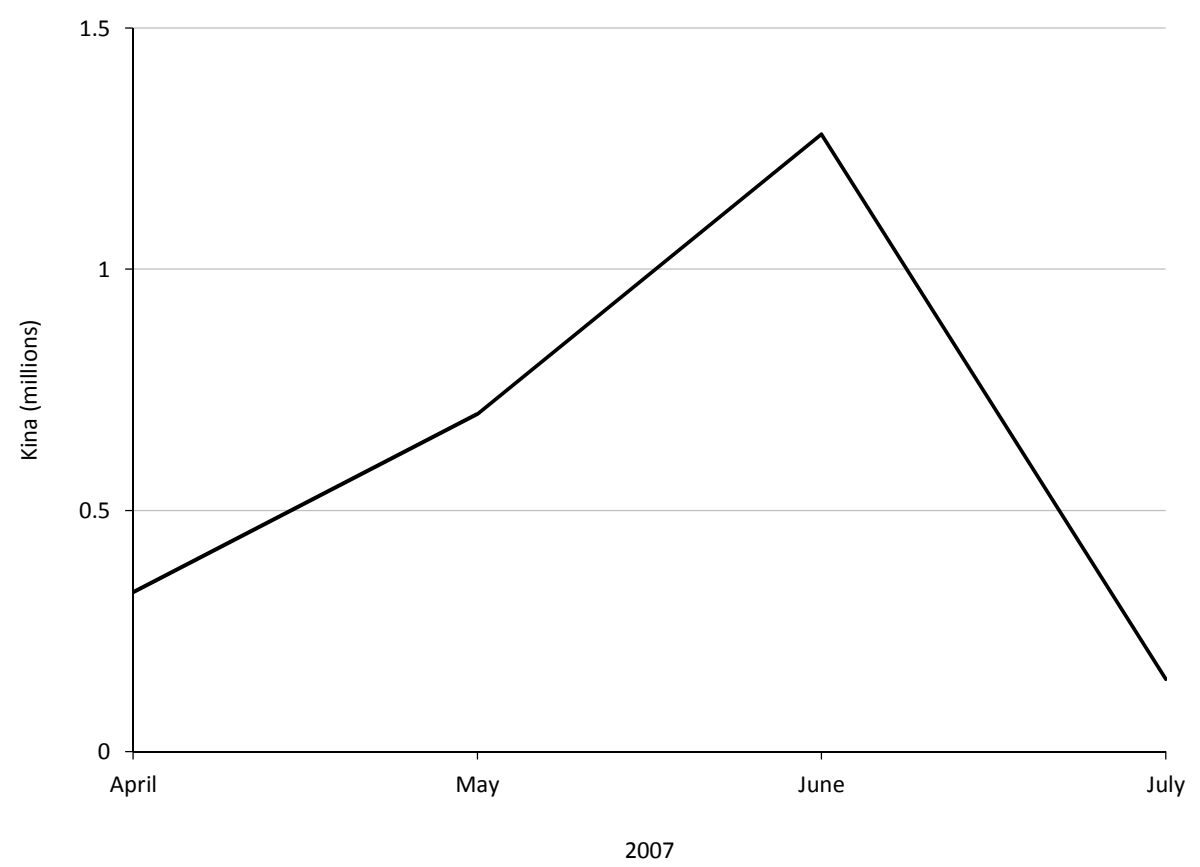

Figure 12.4: Wabag Coca Cola depot income, April-July 2007

Source: Interview with manager, Wabag Coca Cola depot, Wabag, July 2007

\section{Mobility}

One of our field assistants lives very close to a campaign house and made enquiries with people that he knew there. This was done verbally in the third week of June 2007 (part way through the election period) with a purposive sample of 10 males and 10 females who frequented campaign houses. He found that some people stayed away (campaigning) for long periods of time during the election. (We do not know their pattern of behaviour before or after the elections, but the presumption is that mobility enables people to encounter new sexual partners and that without the campaign house they might stay at home more often.)

For many of these people, time away from home was an opportunity for liaisons involving premarital and extramarital sex (see below).

Mobility is not only about people moving between campaign houses but also about people moving between provinces. One woman said that before the campaign period she used to go around with one or two elderly men. However, 
during the campaign period she had a lot of clients including visiting Defence Force and police personnel. She claims that she had 5 to 6 clients a day and made good money during the elections.

\section{Table 12.2: Number of days people stayed away from their homes}

\begin{tabular}{|c|c|c|}
\hline Participant & Day/s out & Marital status \\
\hline \multicolumn{3}{|l|}{ Female } \\
\hline$A$ & since issue of writs ${ }^{a}$ & divorced \\
\hline B & since issue of writs & divorced \\
\hline C & 4 weeks & single \\
\hline D & 4 weeks & single \\
\hline $\mathrm{E}$ & 4 weeks & single \\
\hline $\mathrm{F}$ & 4 weeks & single \\
\hline G & 8 days & married \\
\hline $\mathrm{H}$ & 12 days & married \\
\hline I & 6 days & married woman with children \\
\hline J & many days & married woman with children \\
\hline \multicolumn{3}{|l|}{ Male } \\
\hline A & 1 week & married man with children \\
\hline B & 15 days & married man with children \\
\hline C & many days & married \\
\hline D & many days & married \\
\hline $\mathrm{E}$ & since issue of writs & single \\
\hline $\mathrm{F}$ & 12 days & married \\
\hline G & since issue of writs & single \\
\hline $\mathrm{H}$ & since issue of writs & single \\
\hline I & since issue of writs & single \\
\hline J & since issue of writs & single \\
\hline
\end{tabular}

$a$ Writs were issued on 4 April 2007

\section{Experience of campaign houses}

Campaign houses, or as they are commonly known 'animal houses', are purposely built to house and gather supporters of a particular candidate during the campaign period. The term 'animal house' comes from the reputation campaign houses developed over the years: a lot of people who frequent them seem to act like animals, not thinking sensibly like human beings. During singsings or tanim het, members of opposite sexes whisper to each other and make arrangements to meet outside. A married woman commented, 'Who is to stop them? They have a lot of freedom at that time'. 
Campaigning in Enga, like other Highlands provinces, usually involves generous hospitality and where possible distribution of large sums of cash (Standish 2006). With the introduced limited preferential voting system voters were not restricted to one campaign house but had three or more avenues. Seizing the opportunity of enjoying candidates' free handouts, they moved from one campaign house to another, and if engaging in unprotected sex, posing a greater risk of STI and HIV transmission. Free beverage and food, dusk-todawn gambling, and night entertainment are examples of election spoils from campaign houses. There have been reports of a good deal of sexual activity associated with campaign houses, aided by free alcoholic beverages, drugs and home brew, money, political pressure to win votes, as well as erotic songs sung during the tanim het courting rituals.

\section{Table 12.3: Risky activities and activities leading to people's vulnerability}

\begin{tabular}{ll}
\hline Risky activities & Activities leading to people's vulnerability \\
\hline Premarital and extramarital sex & Singsing, tanim het \\
Sex to win votes & Gambling (cards) \\
Transactional sex & Alcohol and drug abuse \\
Fights resulting in bloodshed & Money \\
& Political pressure \\
\hline
\end{tabular}

A few examples are given here from local people who witnessed activities in campaign houses.

\section{Extramarital sex}

One person reported that during the campaign period, some husbands and wives were no longer seen as married couples. The husband freed himself and so did the wife. If the husband went out to animal houses, the wife went out too. They claimed to have to fight hard to win votes for their candidates.

Another person noted, 'The men said to their wives to free themselves and campaign. No man or woman was to say anything. After the election we would return to our homes and be husbands and wives. Now the women went their own way and the men went their own way during the campaign season. A woman who tried to complain couldn't go on because no one would listen. All complaints would be heard after the election' (35-year-old married woman).

One woman went to an animal house to claim her husband but the man swore at her and told her to wait in their house till the campaign was over and she could claim her husband. She wept and went home.

Although adultery is ordinarily discouraged, some married couples use the elections as a chance to have extramarital affairs. Some married people claim to 
be a yukupae, a local term which means a man or woman who is unattached or separated and therefore available for sex with another yukupae. The 10 men and 10 women from Table 12.2 were asked how many sexual partners they had in the seven weeks from the issue of writs on 4 April 2007. Three women claimed to have had more than 20 different sexual partners over the seven-week period (Figure 12.5).

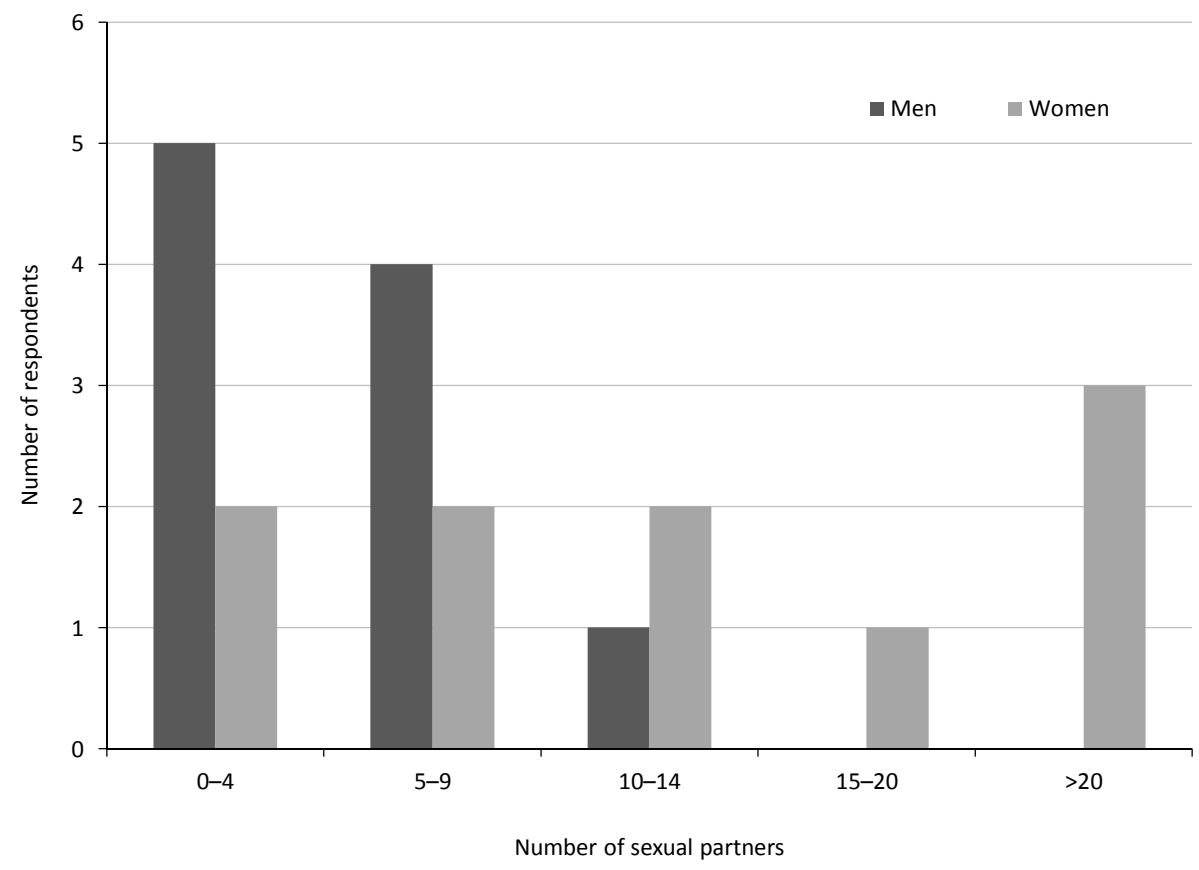

Figure 12.5: Number of sexual partners since issue of the writs

Source: Interviews at marketplace near Wabag, June 2007

\section{Sex for votes}

Women often play a significant role in attracting and entertaining male supporters: young female helpers in campaign houses were sometimes pressured into entertaining males sexually as a way of gaining votes.

... one man came and complained that the girls in there were stubborn and ignorant; she (guardian) got angry with the girls and swore at them saying, 'Yupela stap long plastic o? (meaning, are you virgins?). Why didn't you talk with them at least even if you didn't want to sleep with them?' Then she told them not to come to the animal house because they were useless (from a written account of experience at campaign houses during the 2002 national elections). 
One of the reasons men have multiple sexual partners is to seduce females into voting for their candidate. Some would make false marriage plans with a number of girlfriends. Girls with this type of commitment in mind were easily talked into sex and gave their votes to candidates they did not initially support.

... I want to sex many women or girls in different places so that [a] woman can vote for my candidate with her close relatives and families so that they are convinced that I am going to marry her (married 29-yearold male from near Wabag, 26 May 2007).

\section{Violence}

Physical violence poses a risk of HIV transmission if a wounded and bleeding person is infected. There were a number of election-related deaths and casualties observed in 2007. Dr William Waro from Wabag General Hospital reported one death and two election-related casualties brought to that hospital and the sister in charge at Yampu Health Centre reported 11 men being brought in, some with gunshot and bushknife wounds. These figures do not include a number of postelection casualties.

There is a direct link between engendered sexual violence and HIV transmission (National AIDS Council of Papua New Guinea 2006:18). Stories of rapes associated with campaign houses were reported in past elections, and 2007 was no exception. For example, a woman described a planned rape that occurred at the animal house where she was staying:

One of these girls didn't know that her boyfriend was also at the animal house. When he saw her, she acted shy pretending to hide so he came over to her and asked how she came in. She admitted she came with another guy. She forgot who she came with and joined her old friend. When night came they ate their dinners and started their programs, singing and tanim het. While this was going on, the boyfriend planned the rape of his ex-girlfriend. He told the boys that his girlfriend came in with another guy and he hated her so why don't the guys rape her. This man went into the animal house and asked her if she wanted to chew betel nut and she agreed and decided to come out and chew. They were sitting under a big tree and the man stood up and moved a little way to pee. Then a crowd of men came and carried her away through the kaukau [sweet potato] gardens and they raped her. After they had raped her, they sent her to the animal house and threatened her, telling her to shut up and just sleep. In the morning, the boys contributed K7.00 and gave it to her for her bus fare home. 


\section{Gambling}

Participants of a peer education exercise conducted with the Catholic youth of Sari were asked to identify driving forces behind the HIV epidemic within their communities. Card games were listed among the popular risk practices linked to direct transmission. The youth further explained that when all money is lost in gambling it is possible that people can sell sex. In campaign houses card games were the common entertainment enjoyed by all. At some point sexual terms and phrases were exchanged to signal sex for money. For instance, 'Nyoto dii' ('Give and you'll get it') or 'lay it (card) down! I'll beat it', (meaning lay yourself down and I'll pay for you to continue the game).

\section{Attitudes of people towards sex}

Cultural beliefs and taboos in the past had a strong hold on sexual expression in Enga. For instance, males were instilled with great fear of losing their masculinity through eating food prepared by a female undergoing menstruation. Anthropologist Mervyn Meggitt, writing in the early 1960s, labels Mae Enga men's attitudes to women as the 'anxiety of prudes' trying to protect themselves from contamination by women (Meggitt 1964:222). The resultant distance between the sexes thus naturally delayed sexual exploration at an early age for many, and suppressed promiscuity. Sex was seldom spoken of openly and women had very little say in sexual decision making, though they could be very assertive at times (Kyakas and Wiessner 1992). Women's primary sexual function was that of child bearers.

The social context influencing attitudes and behaviour described by Meggitt has changed dramatically. People in the 30-45 age group have developed new gender-based terminology for sexual matters. Females, for instance, might refer to their sexual organs as 'passbook' (a bank transaction booklet). Phrases such as, 'I can sign my withdrawal slip at any time because I possess a passbook' have been used commonly by females, meaning women have the power to say yes or no to sex for cash. From such sexual terminology one can see a new trend emerging. Women are participating more openly in sexual decision making and there is a more open acknowledgment of transactional sex.

The younger generation speak of sex as a game or a sport, keeping scores and using phrases such as, 'Nambame kanguingi' ('I have broken it', referring to the loss of virginity). Some sexually active people are referred to as 'training centre' or 'service providers'. Youngsters are developing new forms of sexual slang as they experience more freedom in expressing their sexuality. 


\section{Unprotected sex}

Many of the males we spoke with prefer 'skin to skin' sex and have more than one partner. Some sexually active individuals appear careless despite the availability of condoms. A male who claimed to have had six sexual partners during the election period, when asked if he used condoms made the following remarks.

I know most of them are good so I did not use a condom but I used a condom on one. When I tried to use a condom with $\mathrm{X}$, she refused and told me to remove the condom. I knew she was going around with other men but I had to remove the condom and do it because we were both naked and I could not control myself. I am still frightened but I pray that I don't get infected (he is a leader in his church and says that the election has 'spoilt' him).

\section{Multiple sex partners}

The election brought a sense of sexual liberation for many. Some married couples agreed to be 'free' during the campaign period. Males, for boastful reasons, kept tallies of bedded females thus seizing the moment to expand their territories. The following were responses of sexually active males who said they preferred multiple partners as opposed to just one.

... Because I feel tired or fed up of having sex with the same girl or woman and I feel useless.

... I want to keep a record of how many I have sexual intercourse with in order to outnumber other boys/men.

... I like different flavours from different age groups. I like very young girls or virgins because I enjoy sex ... very sweet and much better than older women.

... I want to have many sexual partners in different places so that whenever I am stranded they may accommodate me in their homes.

... I like convincing and sexing many girls/women by telling them that I will marry them so that they can vote for the candidate I support.

... I want to sex many girls or women to marry them so that my brother in laws can support me or my clansmen whenever tribal fighting arises.

... It is useless just sexing the same girl over and over again.

... Sex is my game, my favourite game. 
Groups of sexually active woman displayed similar attitudes to men but their reasons for multiple partnering were either money related or sex for fun. One said that she normally had sex with men or boys behind her husband's back before the election period. During the campaigning period, the limited preferential voting system gave her the opportunity to skip from one campaign house to another, totalling seven campaign houses. She looked for men with money and did not really care about protective measures like condoms.

Another woman said that she used to be a faithful wife but started to go out with multiple sex partners during the election period. She did this to earn money in order to return her husband's brideprice when he returns, as she plans to divorce her husband.

Some women just enjoy the opportunity for new sexual relationships. One divorced woman reported to our field assistant, 'There is no secret in this. I have made deals for other men and girls to have sex. I did it too'. When asked how often she was doing it, she said, 'I did not miss a chance because, you know, every time I am asked I have to go for it. That way I have money for smoke, betel nut and gambling. If I don't go nobody is going to give me anything'.

\section{Viral load and HIV infection}

The infectiousness of people with HIV, which is related to the amount of virus present in the body, varies with the stage of infection (San Francisco AIDS Foundation 2007:1). Immediately after HIV infection, before the immune system produces antibodies in response to its presence, HIV multiplies rapidly. It can take two or more months for the body to produce antibodies to the virus. ${ }^{2}$ People at this stage have a high viral load and the probability of infecting others through unprotected sex is significantly higher than when the viral load is lower. One research study estimated the risk of infection to be 20 times higher (AIDS.org Fact Sheet 2007:2).

Studies have also shown that the rate of infection in communities varies according to whether people tend to have serial partners (one sexual relationship is followed by another, but a person has only one partner at any one time) or concurrent relationships (a number of regular steady relationships at the same time). In the latter case the chance of infection spreading rapidly is greatly increased (Epstein 2007).

The situation in Enga during the elections differed from both these scenarios. In Enga, many campaign houses were open during the three months of the election period, a time, as this research shows, of significantly heightened sexual

2 Elizabeth Reid, personal communication, 7 February 2008, Canberra. 
activity for both men and women. These factors could lead to a considerable amplification of the epidemic. If people were to become newly infected during this time period, they could pass the infection on to a number of their sexual partners who, unaware that they are infected, would themselves move into a period of increased infectiousness and in turn transmit the infection to their sexual partners. For example, a young man may become infected and in the following weeks visit a number of campaign houses and have unprotected sex with several partners at each of those houses. In the week or two after being infected he will carry a high viral load and if a condom is not used there is a high chance that he will pass on the virus to his partners. These partners in turn will be highly infectious in the weeks following and pass the virus on to their partners. With the election period extending over two or three months, there is time for the cycle to be repeated a number of times, leading to a very high rate of transmission of the HIV virus in the community. This is what makes the election period a particularly high-risk event.

\section{Conclusion}

We chose a number of indicators to help us learn about trends in sexual behaviour, particularly during the election period. Our data suggest that despite the lack of baseline studies for comparison, election time is a period of increased freedom, including sexual freedom. In this context many people seem unable or unwilling to protect themselves from HIV infection because of personal, cultural or other forces. There is an urgent need for further study on vulnerability to HIV and the interrelationships between attitudes, behaviour, culture, contexts, ideologies, norms and values (UNAIDS 1998). The extensive multi-partnering over a short period of time can fuel what Jenkins calls a widespread 'hot' epidemic which puts many people at risk (Jenkins and Buchanan-Aruwafu 2007:53).

This study has raised the important issue of viral load and HIV infection in the context of heightened sexual activity over a limited period of time during the election event. Mobility, money and sexual freedom could well mean a period of increased infectiousness as people transmit the virus to their multiple sexual partners during their rounds of campaign houses and other venues. It is not only high-risk groups that one should be concerned about, but also high-risk 'events'. In Enga, elections are a high-risk event.

Hopefully, lessons can be learned from this study. For example, the Sari Youth Drama Group played a limited but significant role in awareness during the election period, performing short 3-5 minute long plays on stigma and discrimination, violence against women, and general risk activities. A lot more could be done to develop participatory methods for designing educational 
messages, and behaviour change programs. Ways to deliver care and treatment need to be adapted to local conditions and concepts. In the months following the elections, local leaders came with large numbers of their communities to be tested for HIV at the Yampu Health Centre near Wabag. People were saying: 'We vote in groups and we want to be tested in groups'. Admittedly the power of the group can have undesirable consequences, as in pack rape. How then can group solidarity be utilized to ensure the wellbeing and the survival of families and clans?

Community mobilization may be one of the most effective means of minimizing further spread of HIV. A good example during the elections was the response of the people of Par in the Ambum-Kompiam electorate. This Tambukini community of 6000 people decided not to host a single campaign house in their area during the 2007 election period. When asked why, a community leader said, 'Because of lessons learnt as we realized there are so many problems brewing from campaign houses'. This, however, did not stop some people from moving to campaign houses in other areas.

Traditional values surrounding sex and sexuality have little relevance to new options at the level of imagination and practice, particularly with the freedom of the election period. It is crucial that key community persons with political insight identify needs and advocate solutions that will empower communities to develop a safer sexual culture. This requires not simply focusing on elections, money, goods and services, but taking into account the whole of people's lives and the way in which values, particularly community cultural values, relate to sexuality. Baseline studies need to be conducted in preparation for more comprehensive research during the next election.

\section{References}

AIDS.org Information Educations Action Fact Sheet, 2007, 'Acute HIV Infection'. http://www.aids.org/factSheets/103-Acute-HIV-Infection.html Consulted 7 February 2008.

Cousins, Jane, 2007. 'Report on PNG National Elections 2007 HIV Prevention Intervention'. Port Moresby.

Epstein, Helen, 2007. The Invisible Cure: Africa, the West and the Fight against AIDS. New York: Farrar, Straus and Giroux.

Jenkins, Carol and Buchanan-Aruwafu, Holly, 2007. Cultures and Contexts Matter: Understanding and Preventing HIV in the Pacific. Manila: Asian Development Bank. 
Kyakas, Alome and Wiessner, Polly, 1992. From Inside the Women's House: Enga Women's Lives and Traditions. Buranda: Robert Brown and Associates.

Meggitt, Mervyn J., 1964. 'Male-female relationships in the highlands of Australian New Guinea', American Anthropologist, New Series 66(4) Part 2: New Guinea: The Central Highlands, pp. 204-224.

National AIDS Council of Papua New Guinea, 2006. National Gender Policy and Plan on HIV, 2006-2010. Port Moresby.

National AIDS Council Secretariat, Papua New Guinea, 2006. Quarterly Report, December.

NHASP (National HIV/AIDS Support Project), 2005. 'Social Mapping Project'. Enga Province.

San Francisco AIDS Foundation, 2007. 'The Stages of HIV Disease', http://www. sfaf.org/aids101/hiv_disease.html Consulted 7 February 2008.

Standish, Bill, 2006. 'Limited preferential voting in Papua New Guinea; some early lessons', Pacific Economic Bulletin 21(1):195-211.

UNAIDS (United Nations Programme on HIV/AIDS), 1998. Expanding the Global Response to HIV/AIDS through Focused Action: Reducing Risk and Vulnerability: Definitions, Rationale and Pathways. Geneva: UNAIDS. 